九州大学学術情報リポジトリ

Kyushu University Institutional Repository

Studies on Winter Bud Break, Flower Bud Initiation and Initial Flowering in the Genus Camellia

Ee, Seon $\mathrm{Ha}$

Laboratory of Horticultural Science, Faculty of Agriculture, Kyushu University

Uemoto, Shunpei

Laboratory of Horticultural Science, Faculty of Agriculture, Kyushu University

https://doi.org/10.5109/23782

出版情報：九州大学大学院農学研究院紀要. 28 (2/3)，pp.111-122，1983-12. Kyushu University バージョン：

権利関係 : 


\title{
Studies on Winter Bud Break, Flower Bud Initiation and Initial Flowering in the Genus Camellia
}

\author{
Seon Ha Ee and Shunpei Uemoto \\ Laboratory of Horticultural Science, Faculty of Agriculture, \\ Kyushu University 46-01, Fukuoka 81'2 \\ (Received September 30, 1983)
}

\begin{abstract}
SYNOPSIS
To determine the growth cycle involving flowering of the genus Camellia, 68 cultivars of five species were investigated at weekly intervals for three years. In Fukuoka, winter buds were broken from mid-March to late April and flower buds were initiated from early June to late July. The times of initial flowering of cultivars were widely spread, from September in the current year to March in the following year. There is a significant relationship between the times of winter bud break and flower bud initiation, but little relationship between the times of flower bud initiation and initial flowering. Phenological changes during each year were affected by air temperatures. High temperatures promoted flower bud initiation but delayed the development of flower buds.
\end{abstract}

\section{INTRODUCTION}

Some species of Camellia are typical ornamental trees with natural distributions in the evergreen broad leaved forest in Japan, and are scattered from Okinawa to Aomori prefecture (Horikawa, 1972). Historically many cultivars have been differentiated in Japan. These cultivars are mainly derived from C. japonica, C. sasanqua, C. vernalis, C. hiemalis, and C. wabisuhe. There is a lack of ecological and physiological information on Camellia, while many cytological studies concerning variation among species and cultivars have been undertaken.

Recently, there has been an increase in commercial production of Camellia for potted plants and cut flowers, as well as for garden trees. In order to produce Camellia for such forced culture, detailed information on flowering in Camellia is necessary. In Japan, species of Camellia commonly break their winter buds in spring, at which time new shoot growth occurs. This is followed by flower bud initiation in early summer. Some cultivars flower initially in the fall, and others in the spring of the following year.

Bonner (1947) reported that in C. japonica, initiation of flower buds requires high temperatures, and flowering is promoted by low temperatures. A survey of previous reports (Miyazawa, 1937; Kosugi, 1953) showed no obvious morphological differences in flower bud initiation between species of Camellia.

This investigation was carried out to study the following: 
1. The relationships among winter bud break, flower bud initiation and flowering.

2. Phenological differences in flowering among species and cultivars.

3. The effect of temperature on flowering under natural conditions.

\section{MATERIALS AND METHODS}

The Camellia trees used in this study were 9-12 years old and were grown in the field of the Faculty of Agriculture, Kyushu University, Fukuoka. Sixty eight cultivars of the following species were investigated: C. japonica (43 cultivars), C. sasanqua (4 cultivars), C. hiemalis (4 cultivars), C. wabisuke (6 cultivars), and C. vernalis (11 cultivars). The duration of this study was three years, from June, 1980 to March, 1983.

In order to examine the growth cycle involving flowering of Camellia, we investigated two trees of each cultivar at weekly intervals for winter bud break, flower bud initiation and initial flowering. Winter bud break was defined as the time leaves become visible on the buds. From the current shoots, five terminal buds per cultivar were collected and were preserved in FAA (5:5:90 \% by volume) fixing solution. Flower bud initiation was determined by dissection under a binocular microscope, following methods of Kosugi (1953). The date of flower bud initiation of a cultivar was specified as the time when three of the five buds sampled had initiated flower buds. The above checks were conducted mainly on buds which developed early on the trees. Initial flowering was recorded when three flowers on any single tree opened.

To investigate the relationship between temperature and flowering, monthly average maximum and minimum temperatures in Fukuoka were checked for the seasons of 1980-83. Two-year old potted trees of C. vernalis 'Ōmigoromo' were subjected to either $15^{\circ} \mathrm{C}, 20^{\circ} \mathrm{C} 25^{\circ} \mathrm{C}$ or $30^{\circ} \mathrm{C}$ temperatures in the phytotron from May 2 to September 30 (20 trees under each temperature regime). These plants were checked weekly for flower bud initiation and flower bud development.

\section{RESULTS AND DISCUSSION}

In Fig. 1 we present a frequency distribution of cultivars exhibiting winter bud break, flower bud initiation, and initial flowering at weekly intervals during the season of 1982-83 in Fukuoka, southwestern Japan. Monthly average maximum and minimum air temperatures during the seasons 1980-83 in Fukuoka are given in Fig. 2. According to results obtained from 68 cultivars of five species, winter buds of all Camellia species were broken during the period from March 21 to April 25. Average air temperatures during these days were $8.4{ }^{\circ} \mathrm{C}, 17.8^{\circ} \mathrm{C}$, and $12.9 \%$ respectively, for minimum, maximum and mean temperatures. Most cultivars $(82.4 \%)$, moreover, broke their winter buds within a three week period from March 28 to April 18. These results demonstrate that, in general, these Camellia species require an average daily 




Fig. 1. Frequency distribution of winter bud break, flower bud initiation, and initial flowering for 68 Camellia cultivars (5 species), season of 1982-83.

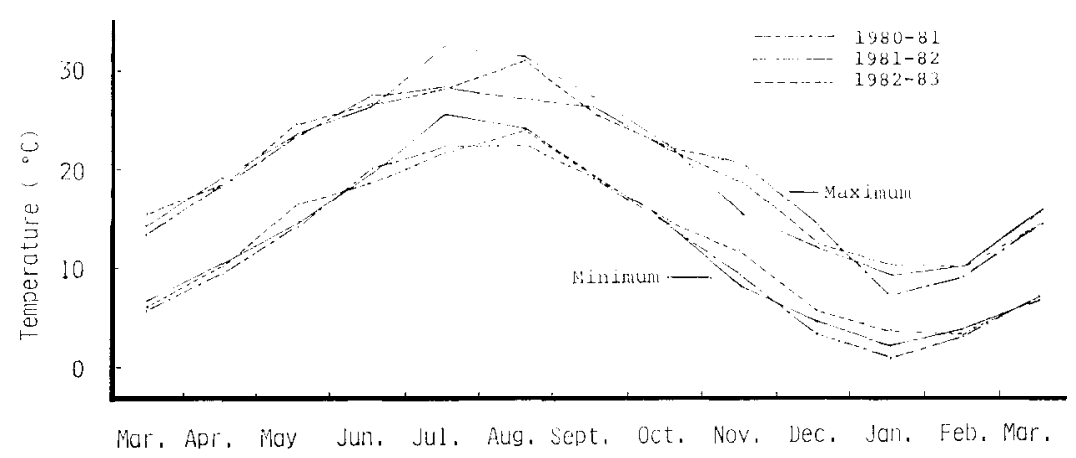

Fig. 2. Monthly average maximum and minimum air temperatures, Fukuoka, seasons of 1980-83.

temperature $12.9^{\circ} \mathrm{C}$ or higher to break their dormancy. The earliest cultivars to break their winter buds, in $121^{\circ} \mathrm{C}$ average daily temperature, were 'AkiNo-Yama' of C. japonica and 'Seiōbo' of C. wabisuke. The latest, in $14.8^{\circ} \mathrm{C}$ average daily temperature, were 'Shira-Giku', 'Shiihd-Karako', and 'Ringo-Tsubaki' of C. japonica (see Appendix).

Flower buds of 68 cultivars were initiated on the current shoots during the period from June 6 to July 25, after the elongation of shoots ceased. On the average, flower bud initiation occurred 12 weeks after winter bud break. Average air temperatures in these days were $20.3^{\circ} \mathrm{C}, 27.3^{\circ} \mathrm{C}$, and $23.5^{\circ} \mathrm{C}$, respectively, for minimum, maximum and mean temperatures. Among all of the cultivars, $79.4 \%$ initiated their flower buds within a three week period, from June 20 to July 11 . The earliest cultivars to initiate flower buds, in $20.4^{\circ} \mathrm{C}$ average daily temperature, were 'Aki-No-Yama' of C. japonica, and 'Seiōbo' of C. wabisuke, and the latest, in $24.3^{\circ} \mathrm{C}$ average daily temperature, were 'Nokogi- 
Table 1. Weeks required to flower bud initiation and to initial flowering in 68 Camellia cultivars, season 1382-83. A: Date of winter bud break B : Date of flower bud initiation C : Date of initial flowering

\begin{tabular}{|c|c|c|c|c|}
\hline & Cultivars & $\begin{array}{c}\text { No. of } \\
\text { cultivars }\end{array}$ & $\begin{array}{l}\text { Mean weeks } \\
\text { from } A \text { to } B\end{array}$ & $\begin{array}{l}\text { Mean weeks } \\
\text { from B to C }\end{array}$ \\
\hline Cultiva & flowering in the cu & 31 & $11.81 \pm 0.12$ & $19.39 \pm 0.51$ \\
\hline Cultivars & flowering in the following year & 37 & $12.22 \pm 0.15$ & $32.95 \pm 0.45$ \\
\hline
\end{tabular}

Table 2. Differences in the time of initial flowering among 5 Camellia species (58 cultivars), season 1982-83.

\begin{tabular}{|c|c|c|c|c|c|c|}
\hline \multirow{2}{*}{ Species } & \multirow{2}{*}{$\begin{array}{l}\text { No. of } \\
\text { cultivars }\end{array}$} & \multicolumn{2}{|c|}{ Cultivars flowering } & \multicolumn{3}{|c|}{$\begin{array}{l}\text { Cultivars flowering } \\
\text { initially during Jan.-Mar. }\end{array}$} \\
\hline & & Number & Period & Number & & Period \\
\hline $\begin{array}{l}\text { C. japonica } \\
\text { C. sasanqua } \\
\text { C. hiemalis }\end{array}$ & $\begin{array}{r}43 \\
3 \\
6\end{array}$ & $\begin{array}{l}7 \\
4 \\
5\end{array}$ & $\begin{array}{lrr}\text { Oct. } & \text { 3-Dec. } & 12 \\
\text { Oct. } & \text { 3-Qct. } & 17 \\
\text { Oct. } & \text { 17-Nov. } 7\end{array}$ & $\begin{array}{l}36 \\
-\end{array}$ & Jan. & Y-Mar. 20 \\
\hline $\begin{array}{l}\text { C. wabisuke } \\
\text { C. vernalis }\end{array}$ & 11 & $1 \mathrm{i}$ & $\begin{array}{l}\text { Sept. 26-Dec. } 19 \\
\text { Oct. 24-Dec. } 12\end{array}$ & 1 & & Jan. 23 \\
\hline
\end{tabular}

riba-Tsubaki' and 'Shikainami' of C. japonica. Cultivars of any particular species showed no pattern in the times at which they broke their winter buds and initiated flower buds.

In Camellia species, the initial flowering period was widely spread, from early September to late March of the following year, although winter bud break and flower bud initiation occurred in a short period. Cultivars of Camellia have been commonly classified into groups: those flowering in the fall and those flowering in the spring (Sealy, 1958; Hagiya et al., 1978). However, in this study we would rather divide the cultivars into those flowering in the current year and those flowering early in the following year, because initial flowering in the various cultivars took place continuously from fall of the current year to spring of the following year.

The period from flower bud initiation to initial flowering was quite different between cultivars flowering in the current year and those flowering in the following year, whereas there was little difference in the period from winter bud break to flower bud initiation (Table 1). Table 2 shows that among cultivars flowering initially in the current year, cultivars of C. sasanqua had initial flowering early in the fall, cultivars of $\mathrm{C}$. hiemalis and C. vernalis had their initial flowering in the midterm, from October to December, and those of C. wabisuke appeared to be variable in initial flowering date. Most cultivars which flowered initially in winter and spring of the following year were those of C. japonica. Some cultivars of C. japonica, however, flowered initially in the fall. Among three Camellia species flowering in the midterm, seven cultivars of C. vernalis initially flowered generally in the intermediate period between C. japonica and C. sasanqua, as Makino (1905) has described. Uemoto et al. (1980) suggested, on the basis of cytogenetic studies, that C. vernalis was a species of hybrid origin between C. japonica and C. sasanqua. The results of analyses of 
pigments by Sakata et al. (1981) revealed that the anthocyanin constitution of $C$. vernalis was clearly intermediate between these species. In the Fukuoka area, the early flowering date of the wild form of C. japonica (December 5) supports the assertion of Uemoto et al. (1980) that C. vernalis was derived from natural crossing between C. japonica and C. sasanqua due to overlapping of flowering time. It is interesting that the flowering time as well as the pattern of anthocyanins in the flower petal of $\mathbf{C}$. hiemalis appear to be close to those of C. sasanqua, but the time of flowering of C. wabisuke was widely spread, and its pattern of anthocyanins was variable.

Camellia japonica cultivars flowering initially in the current year were 'AkiNo-Yama', 'Hatsu-A rashi', 'Taroan', 'Shiro-Karako', 'Taiheiraku' as well as the wild form. The flowering date of the wild forms in this area was quite early as compared to those in the Kansai area (Nishio, 1980). Therefore, it is assumed that some of the earlier flowering cultivars have been selected from the wild forms in areas with high temperatures. Hagiya et al. (1978) analyzed flower buds to detemine if endogenous substances are related with flowering of Camellia. They suggested that inhibitors control flowering of Camellia, and that in C. japonica and C. sasanqua, different inhibitors are related to flowering. If we accept this suggestion, then the C. japonica cultivars flowering in the following year seem to require a longer time and lower temperatures to remove those inhibitors than do other cultivars or other species.

Figure 1 shows that Camellia, in general, breaks winter buds during March to April and initiates flower buds during June to July, then flowers initially



Fig. 3. Relationship between flower bud initiation and winter bud break in 48 Camellia cultivars, season of 1981 . O one or two cultivars; $\mathbf{O}$, three to five cultivars; 0 , six or more cultivars; **, significant at $1 \%$ level. 


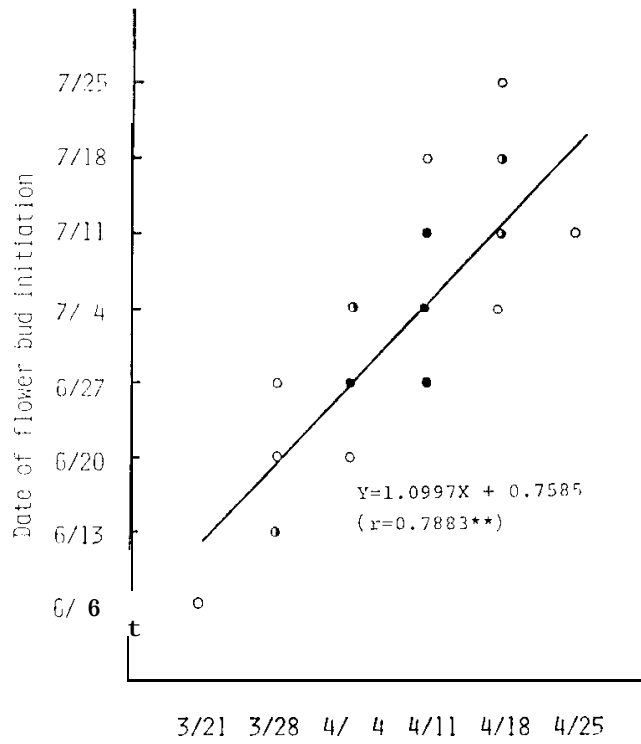

Date of wi nter bud break

Fig. 4. Relationship between flower bud initiation and winter bud break in 68 Camellia cultivars, season of 1982 . O, one or two cultivars; $\mathbf{J}$, three to five cultivars; 0 , six or more cultivars; **, significant at $1 \%$ level.

from fall to spring depending on the cultivar. To determine the interrelation among the three stages in the growth cycle of Camellia, we examined the relationship between winter bud break and flower bud initiation, and between flower bud initiation and initial flowering. There was a significant relationship between the time of winter bud break and the time of flower bud initiation. For example, cultivars that broke their winter buds early also initiated their flower buds early. We gained similar results for two years as seen in Fig. 3 and 4. Hagiya and Ishizawa (1966) reported that this tendency was revealed strongly in the wild form of C. japonica subsp. rusticana. The results above indicate that if we try to promote flower bud initiation in forced culture, it requires that winter buds also be broken earlier.

As presented in Fig. 5, we could not find any significant relationship between flower bud initiation and initial flowering, while there was a highly significant relationship between winter bud break and flower bud initiation. The lack of a relationship in the former case might be attributed to differences in dormancy of flower buds among cultivars. There may be different responses of various cultivars to temperatures.

Among species and cultivars, the phenological changes of winter bud break, flower bud initiation and initial flowering were correlated with temperature for three years. Fig. 6 shows no clear difference between 1981 and 1982 in the cumulative number of cultivars with breaking winter buds, recorded at weekly intervals. These results might be attributed to little difference in 


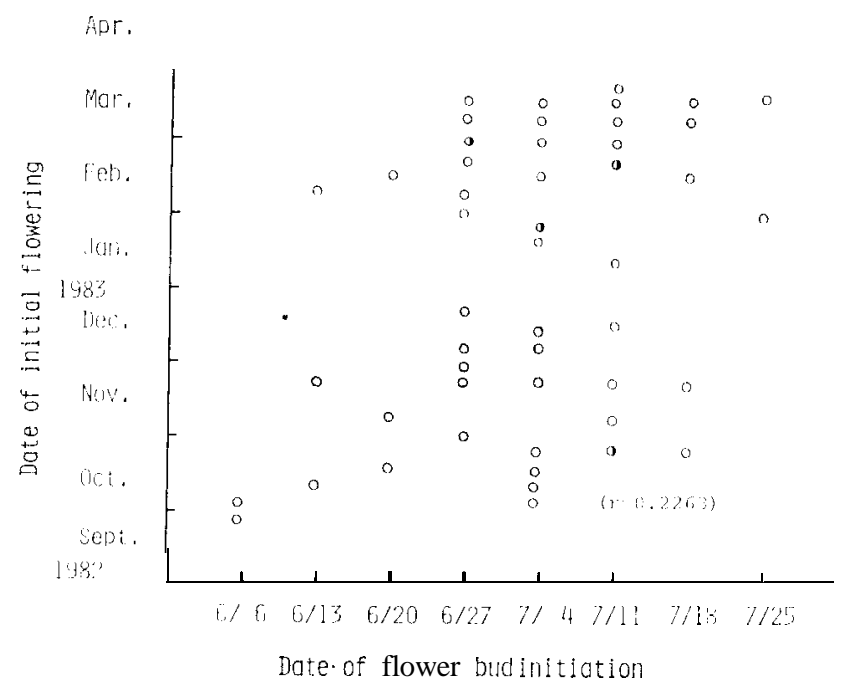

Fig. 5. Relationship between initial flowering and flower bud initiation in 68 Camellia cultivars, season of 1982-1983. O, one or two cultivars; three cultivars.

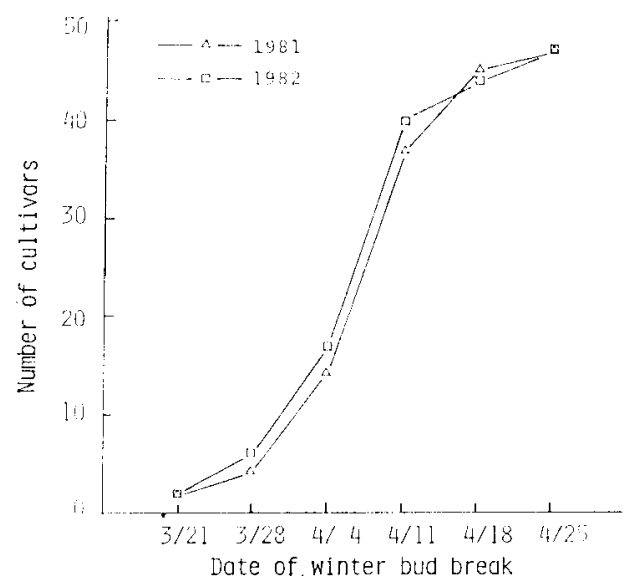

Fig. 6. Cumulative number of Camellia cultivars with breaking wirter buds, observed at weekly intervals during the seasons of 1981-82.

temperature between these two years. Mean air temperatures during these weeks were $13.4^{\circ} \mathrm{C}$ in 1981 and $12.9^{\circ} \mathrm{C}$ in 1982 . Therefore we suggest that in Fukuoka, Camellia breaks its winter buds during five weeks, from March 21 to April 25, if temperatures are similar to those in 1981 and 1982 . We could find no significant difference among the seasons of 1980-83 in the cumulative number of cultivars with initiating flower buds recorded at weekly intervals (Fig. 




Fig. 1. Cumulative number of Camellia cultivars with initiated flower buds, observed at weekly intervals during the seasons of 1980-82.

7). All of the cultivars checked initiated their flower buds during seven weeks, from June 6 to July 25. During these weeks, mean air temperatures were $24.1^{\circ} \mathrm{C}$ in $1980,26.0^{\circ} \mathrm{C}$ in 1981 , and $23.5^{\circ} \mathrm{C}$ in 1982 , and average minimum temperature of the three years was $21.5^{\circ} \mathrm{C}$. Tomita et al. (1974) investigated 66 cultivars of Camellia in Saitama in the Kantō area and reported that flower bud initiation occurred during mid-June to early August. This period was about a week later than in Fukuoka. This delay seems to be caused by the difference in temperature between the two areas. Mean air temperature



Fig. 8. Cumulative number of Camellia cultivars reaching initial flowering, observed at weekly intervals during the seasons of 1980-83. 




Fig. 9. Development of flower buds under various temperature conditions (C. vernalis 'О̄migoromo').

during March to August was $18.8^{\circ} \mathrm{C}$ in Saitama (1973) and $19.9^{\circ} \mathrm{C}$ in Fukuoka (1982). As suggested by Bonner (1947), high temperatures, above $15^{\circ} \mathrm{C}$, may be essential for flower bud initiation. However, flower bud initiation occurred in no cultivars during May although the average minimum temperature was above $15^{\circ} \mathrm{C}$. This indicates that high temperature alone is not sufficient to initiate flower buds. Presumably, a certain degree of maturity of shoots is also a precondition. When both conditions are present, initiation of flower buds progresses.

During the season of 1981-82, the dates of initial flowering of all cultivars were delayed by an average of 3.4 weeks, as compared to the season of 1982 83 (Fig. 8 and Appendix). A look at seasonal changes in temperature from March, 1980 to March, 1983, revealed that temperatures from mid-June to late August, 1981 were higher than those of other years (Fig. 2). The delayed flowering in this year is considered to be related to these high temperatures. The development of flower buds under high temperature conditions $\left(25^{\circ} \mathrm{C}, 30^{\circ} \mathrm{C}\right)$ made slower progress than under low temperatures $\left(15^{\circ} \mathrm{C}, 20^{\circ} \mathrm{C}\right)$, whereas high temperature hastened flower bud initiation (Fig. 9). After flower bud initiation, floral organs are differentiated immediately in the following order: petals, stamens, pistil, ovules and pollen; and these organs develop rapidly. It takes approximately 40 days for ovules to differentiate after flower bud initiation, although it takes an average of 189 days to initial flowering (Ee et al., 1981). According to results presented above, high temperatures seemed to delay development during the early stage, resulting in delayed flowering.

\section{REFERENCES}

Bonner, J. 1947 Flower bud initiation and flower opening in the Camellia. Proc. Amer. Soc. Hort. Sci., 50: 401-408

Ee, S. H., S. Uemoto and T. Tanaka 1981 Ecological studies on the genus Camellia. Proc. 
Ann. Autumn Meeting Japan. Soc. Hort. Sci. for 1981: 262-263 (in Japanese)

Hagiya, K. and S. Ishizawa 1966 Differences between C. japonica subsp. rusticana and $C$. japonica in the development phases of flower and leaf buds. Proc. Ann. Spring Meeting Japan. Soc. Hort. Sci. for 1966: 303-304 (in Japanese)

Hagiya, K., H. Kato and M. Funane 1978 Flowering and change in endogenous growth regulators of flower buds in the genus Camellia. Proc. Ann. Autumn Meeting Japan. Soc. Hort. Sci. for 1978: 294-295 (in Japanese)

Hakoda, N., J. Takenaga, M. Matsumoto and K. Terakado 1971 Studies of cultivars of Camellia sasanqua. 1. Blooming season and morphological characteristics and variation of flowers. Proc. Ann. Spring Meeting Japan. Soc. Hort. Sci. for 1971: 228-229 (in Japanese) Horikawa, Y. 1972 Atlas of the Japanese flora, Gakken Co., Ltd. Tokyo, Japan, p. 217

Kosugi, K. 1953 Studies of the flower bud differentiation and development in some ornamental trees and shrubs. 1. On the time of flower bud differentiation and process of flower bud development in Camellia japonica L. var. hortensis Makino and C. sasanqua Thunb. J. Japan. Soc. Hort. Sci., 22: 50-54 (in Japanese)

Makino, T. 1905 Observations on the flora of Japan. Bot. Mag. Tokyo, 19: 135-136

Miyazawa, B. 1937 The time of flower bud initiation of tea. Agriculture and Horticulture, 12 (4) : 1084-1092 (in Japanese)

Nishio, A. 1980 Studies on the weather and flowering in Camellia. Tsubaki, 19: 65-69 (in Japanese)

Sakata, Y., S. Nagayoshi and K. Arisumi 1981 Studies on the flower colours in the Camellia. II. On the anthocyanin constitution in the cultivars of C. japonica, C. japonica subsp. rusticana, C. sasanqua, C. hiemalis, C. vernalis and C. wabisuke. Mem. Fac. Agr. Kagoshima Univ., 17: 79-94

Sealy, J. R. 1958 A revision of the genus Camellia. Royal Hort. Soc., London, pp. 239

Tomita, H., T. Uematsu and T. Saito 1974 On the time of flower bud initiation of 66 cultivars of C. japonica and C. sasanqua. Proc. Ann. Autumn Meeting Japan. Soc. Hort. Sci., for 1974: 290-291 (in Japanese)

Uemoto, S., T. Tanaka and K. Fujieda 1980 Cytogenetic studies on the origin of Camellia vernalis. 1. On the meiotic chromosomes in some related Camellia forms in Hirado island. J. Japan. Soc. Hort. Sci., 48(4): 475-482 
Appendix: Dates of winter bud break. flower bud initiation and initial flowering in the genus Camellia.

\begin{tabular}{|c|c|c|c|}
\hline & & & \\
\hline Cultivar & $\begin{array}{l}\text { Date of } \\
\text { breaking } \\
\text { winter } \\
\text { buds } \\
\text { (A) }\end{array}$ & $\begin{array}{l}\text { Date of } \\
\text { initiating } \\
\text { flower } \\
\text { buds } \\
\text { (B) }\end{array}$ & $\begin{array}{l}\text { Weeks } \\
\text { from } \\
\text { A to B }\end{array}$ \\
\hline
\end{tabular}

$\begin{array}{ccc}\begin{array}{c}\text { Date of flowering } \\ \text { initially }\end{array} & \text { Weeks } & \begin{array}{c}\text { Weeks } \\ \text { from }\end{array} \\ \begin{array}{cccc}1981-82 & 1982-83 & \text { Bto D } \\ \text { (C) } & \text { (D) } & \text { (C-D) } & \end{array}\end{array}$

\section{C. japonica}

Aki-No-Yama

Hatsu-Arashi

Akebono

Tarōan

Wild form

Shiro-Karako

Taiheiraku

Shira-Giku

cv. 1

Hakkaku

Sōshi-Arai

Nokogiriba-Tsubaki

Shiro-hitoe

Kingyoba-Tsubaki

cv. 2

Kuni-No-Hikari

Sakura-Tsukasa

Kō-Botan

Akashi-Gata

Higo-Kyo-Nishiki

Hikaru-Genji

Higo-Egao

Sakura-Gari

Moshio

$\bar{O}_{n i j i}$

Asagao

Yamato-Nishiki

Kumagai

Beni-Karako

Kömyō

Haku-botan

Harugasumi

Shūhō-Karako

Higo-Kumagai

Kansai-Hagoromo

Kyo-Karako

Sode-Kakushi

Mikenjaku

Takara-Awase

Ezo-Nishiki

Jitsugetsu-Sei

Shikainami

Ringo-Tsubaki

C. sasanqua

Meigetsu

cv. 1

cv. 2

cv. 3

\section{C. hiemalis}

Showa-No-Sakae Otome

Fuji-No-Mine

Tachikan-Tsubaki
Mar. 21 June 6

Mar. 28 June 13

Mar. 28 June 20

Apr. 11 July 4

Apr. 4 June 27

Apr. 11 July 4

Apr. 11

Apr. 25

Apr. 11

Apr. 11

Apr. 18

Apr. 4

Apr. 11

Mar. 28

July

July 11

July 4

July 4

July 4

July 25

June 27

June 27

Apr. 4 June 27

Apr. 11 July 18

Apr. 4 July 4

Mar. 28 June 20

Apr. 11 July 11

Apr. 4 June 27

Apr. 4 June 27

Apr. 11 July 11

Apr 4 June 27

Mar. 28 June 27

Apr. 11 June 27

Apr. 11 July 11

Apr. 18 July 4

Apr. 11 July 11

Apr. 4 June 27

Apr. 4 July 4

Apr. 25 July 11

Apr. 18 July 18

Apr. 11 July 4

Apr. 4

Apr. 4

Apr. 18

July 4

July 18

July 11

Apr. 11

Apr. 4 June 27

Apr. 18 July 25

Apr. 25

July 11

Apr. 11

Apr. 18

Jul

Apr. 11

July 11

July

Apr. 4 June 20

Apr. 18 July 11

Apr. 11

July 4

Apr. 11
July 11

\section{2 \\ 12 \\ 12 \\ 12 \\ 11 \\ 12 \\ 12 \\ 14 \\ 12 \\ 11
11 \\ 11 \\ 11 \\ 14 \\ 13 \\ 12 \\ 13 \\ 12 \\ 13 \\ 12 \\ 13 \\ 11 \\ 13 \\ 11

11
11
12

Nov. 21

Nov. 14

Dec. 12

Jan. 9

Jan. 9

Dec. 19

Dec. 26

Feb. 13

Fed. 20

Jan. 30

Feb. 20

Feb. 27

Jan. 30

Mar. 6

Feb. 20

Mar. 6

Mar. 6

Mar. 6

Mar. 13

Feb. 27

Mar. 20

Mar. 20

Mar. 20

Mar. 13

Mar. 13

Mar. 20

Mar. 13

Mar. 20

Mar. 6

Mar. 6

Mar. 13

Mar. 20

Mar. 20

Mar: 23

Mar. 20

Mar. 20

Mar. 13

Mar. 27

Mar. 20

Mar. 13

Mar. 20

Oct. 3

Oct. 10

Nov. 7

Dec. 5

Dec. 5

Dec. 12

Dec. 5

Jan. 9

Jan. 16

Jan. 23

Jan. 23

Jan. 30

Jan. 30

Jan. 30

Feb. 6

Feb. 6

Feb. 6

Feb. 13

Feb. 13

Fed. 13

Feb. 20

Fed. 20

Feb. 20

Feb. 27

Feb. 27

Feb. 27

Feb. 27

Feb. 20

Feb. 27

Feb. 27

Mar. 6

Mar. 6

Mar. 6

Mar. Mar. 66

Mar. 13

Mar. 13

Mar. 13

Mar. 13

Mar. 13

Mar. 13

Mar. 13

Mar. 20

Oct. 31

Oct. 3

Oct. 10

Oct. 17

Oct. 17

Oct. 17

Nov. 7

Nov. 7

Oct. 17

Nov. 28

Oct. 24

Oct. 24

Nov. 7

17

17

20

23 
Appendix: (Continued)

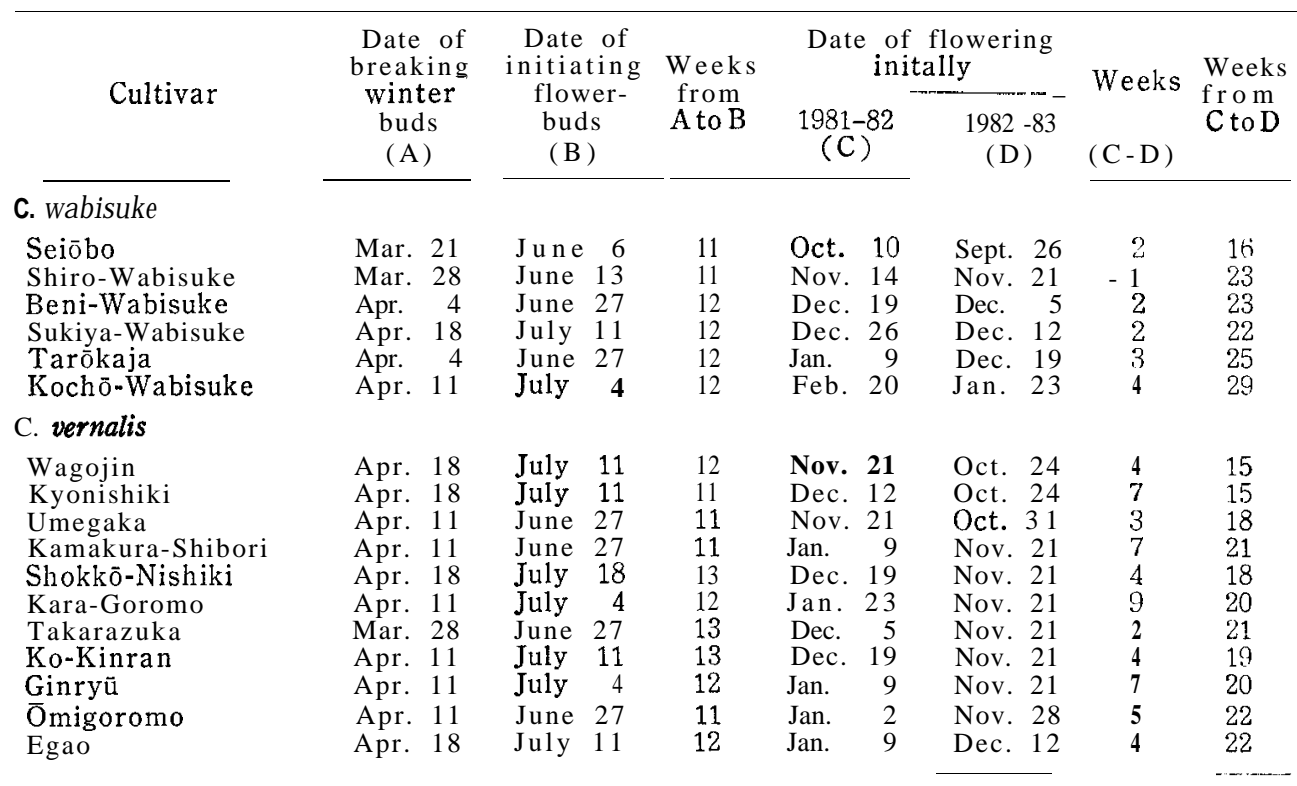

